Prepared in cooperation with City of Grandview, Missouri

\title{
Precipitation-Driven Flood-Inundation Mapping of the Little Blue River at Grandview, Missouri
}

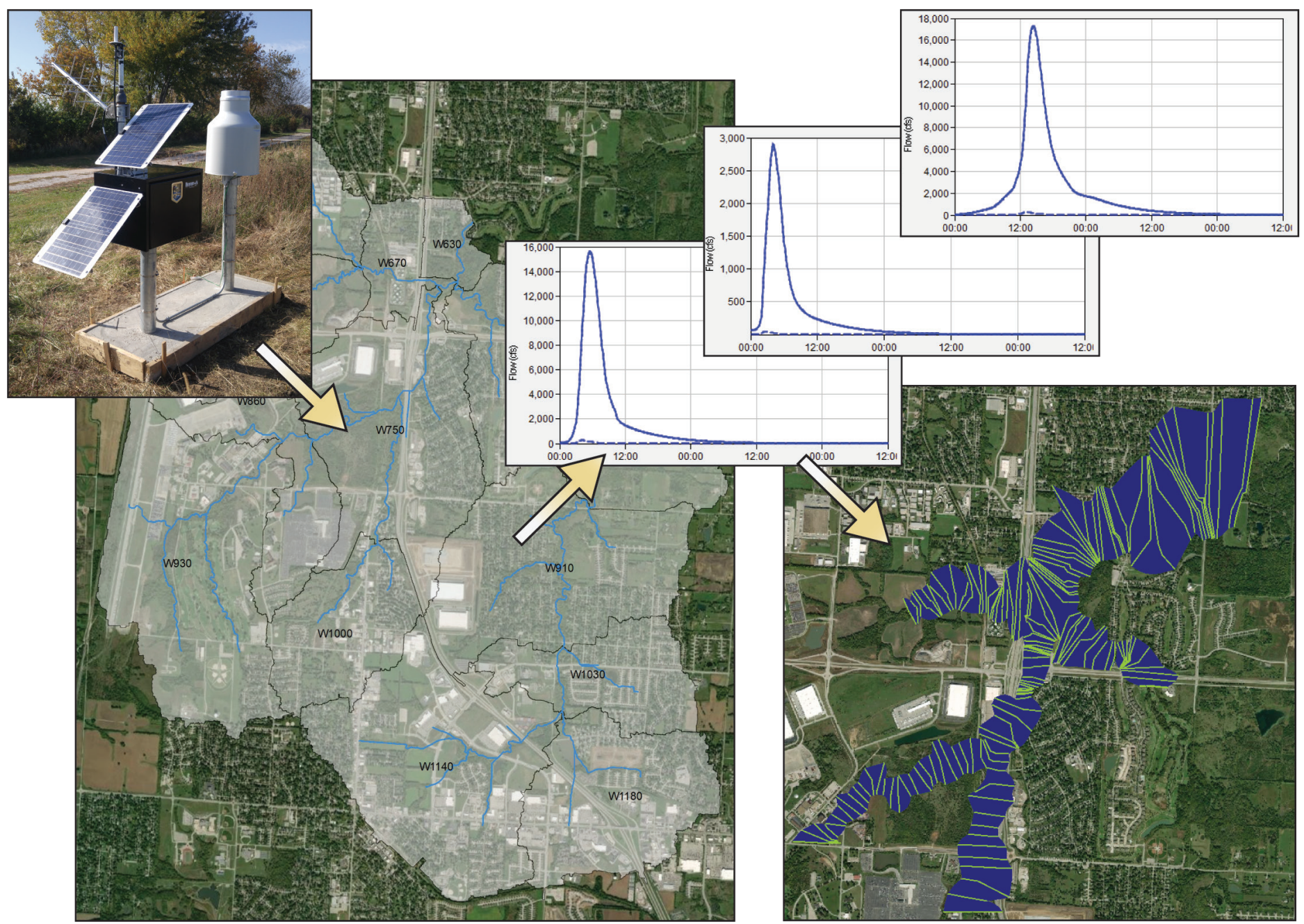

Scientific Investigations Report 2021-5068

Version 1.1, January 2022 
Cover: Images showing (from top left to bottom right) precipitation-only gage (photograph taken at Eagles' Landing Golf Course in Belton, Missouri, on October 25, 2019, by Daniel Armstrong, U.S. Geological Survey), U.S. Army Corps of Engineers Hydrologic Engineering Center-Hydrologic Modeling System model basin and streamflow hydrographs, and U.S. Army Corps of Engineers Hydrologic Engineering Center-River Analysis System depiction of flood-inundation area and model cross sections. 


\section{Precipitation-Driven Flood-Inundation Mapping of the Little Blue River at Grandview, Missouri}

By David C. Heimann, Jonathon D. Voss, and Paul H. Rydlund, Jr.

Prepared in cooperation with City of Grandview, Missouri

Scientific Investigations Report 2021-5068

Version 1.1, January 2022 


\section{U.S. Geological Survey, Reston, Virginia: 2021}

First release: 2021

Revised: January 2022 (ver. 1.1)

For more information on the USGS - the Federal source for science about the Earth, its natural and living resources, natural hazards, and the environment-visit https://www.usgs.gov or call 1-888-ASK-USGS.

For an overview of USGS information products, including maps, imagery, and publications, visit https://store.usgs.gov/.

Any use of trade, firm, or product names is for descriptive purposes only and does not imply endorsement by the U.S. Government.

Although this information product, for the most part, is in the public domain, it also may contain copyrighted materials as noted in the text. Permission to reproduce copyrighted items must be secured from the copyright owner.

Suggested citation:

Heimann, D.C., Voss, J.D., and Rydlund, P.H., Jr., 2021, Precipitation-driven flood-inundation mapping of the Little Blue River at Grandview, Missouri (ver. 1.1, January 2022): U.S. Geological Survey Scientific Investigations Report 2021-5068, 19 p., https://doi.org/10.3133/sir20215068.

Associated data for this report:

Heimann, D.C., and Voss, J.D., 2021, Archive of hydrologic models used to generate flood peaks based on selected precipitation durations and recurrence intervals for the Little Blue River Basin, Grandview, Missouri: U.S. Geological Survey data release, https://doi.org/10.5066/P9G68J00.

U.S. Geological Survey, 2020, USGS water data for the Nation: U.S. Geological Survey National Water Information System database, https://doi.org/10.5066/F7P55KJN.

Voss, J.D., and Heimann, D.C., 2021, Geospatial data and hydraulic-model archive for evaluation of flood-inundation maps developed for a reach of the Little Blue River at Grandview, Missouri: U.S. Geological Survey data release, https://doi.org/10.5066/P9JLOM4K.

ISSN 2328-0328 (online 


\section{Acknowledgments}

The authors wish to acknowledge funding provided by the City of Grandview, Missouri, for this study along with the continued support from the City of Grandview in funding the U.S. Geological Survey streamgage, Little Blue River at Grandview, Mo., and two precipitationonly gages within the upper Little Blue River study basin. 



\section{Contents}

Acknowledgments ……...................................................................................................................

Abstract

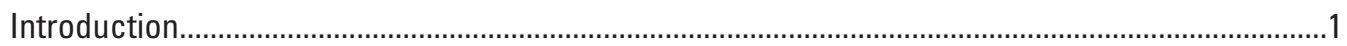

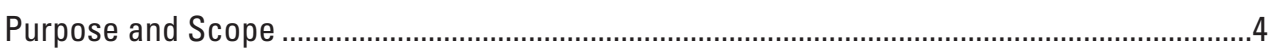

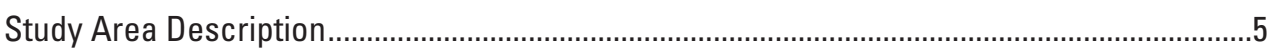

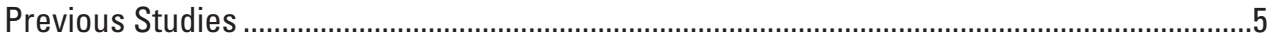

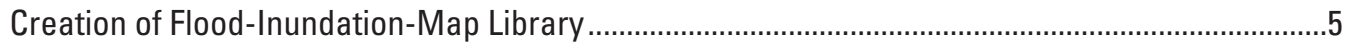

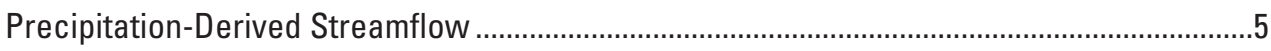

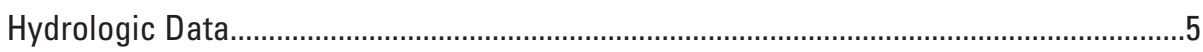

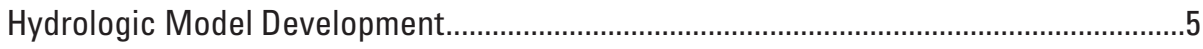

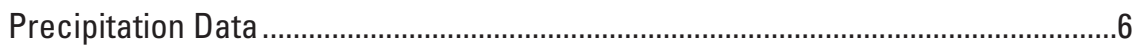

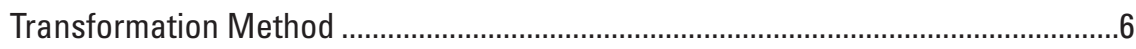

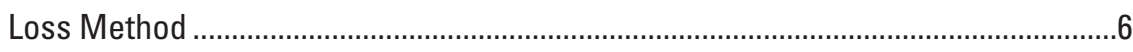

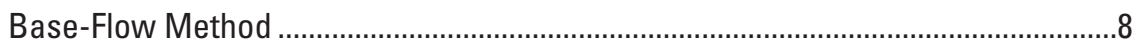

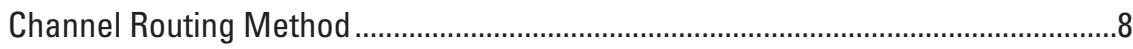

Hydrologic Model Calibration ......................................................................................

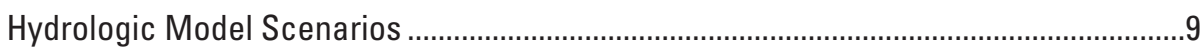

Computation of Water-Surface Profiles.............................................................................

Topographic and Bathymetric Data ..............................................................................

Hydraulic Structures .................................................................................................

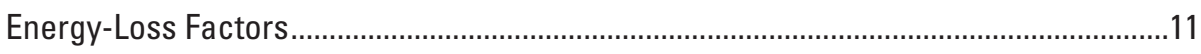

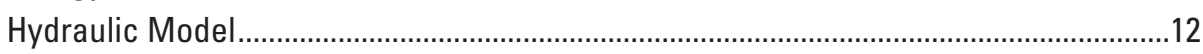

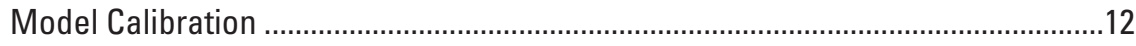

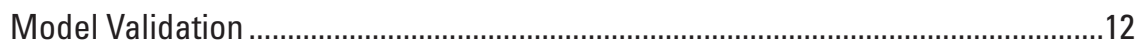

Development of Water-Surface Profiles........................................................................13

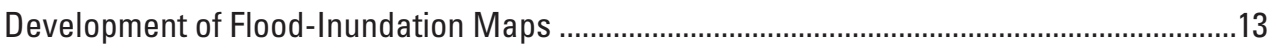

Flood-Inundation Map Delivery ................................................................................13

Disclaimer for Flood-Inundation Maps ………………….......................................16

Uncertainties and Limitations Regarding Use of Flood-Inundation Maps .......................16

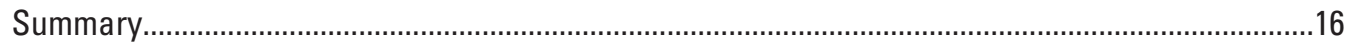

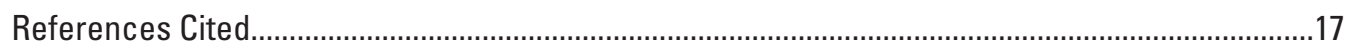

\section{Figures}

1. Map showing location of city of Grandview and upper Little Blue River study basin ......2

2. Map showing U.S. Army Corps of Engineers Hydrologic Engineering Center-Hydrologic Modeling System model basin and subbasins, Hydrologic Engineering Center-River Analysis System model cross sections, HEC-RAS reach flow input locations, and extent of flood-inundation maps.

3. Graphs showing relations between Atlas 14 precipitation totals and durations used in interpolating 4- and 8-hour precipitation totals for recurrence intervals of 1 to 500 years

4. Graph showing simulated and observed streamflow from the May 28, 2020, high-flow event at the Little Blue River at Grandview, Missouri.. 
5. Map showing simplified 2016 land-cover categories for the upper Little Blue River study basin.

6. Map showing simplified future land-cover categories for the upper Little Blue River study basin.

7. Map showing flood inundation for the Little Blue River at Grandview, Missouri, study reach corresponding to a stage of 23.0 feet at the U.S. Geological Survey streamgage 06893750 .

8. Decision process in determining the hydrologic response, including estimated stage and corresponding flood-inundation map, from observed accumulated precipitation.

\section{Tables}

1. Description of U.S. Geological Survey streamgage at Little Blue River at

Grandview, Missouri

2. Description of U.S. Geological Survey precipitation-only gages in the Little Blue River study basin.

3. Simulated and observed hydrograph characteristics of the May 28-29, 2020, high-flow event at the Little Blue River at Grandview, Missouri, streamgage.

4. Estimated streamflows for corresponding stages and water-surface elevations at selected flow-change locations used in the hydraulic model of the Little Blue River at Grandview, Missouri.

5. Calibration of hydraulic model to target high-water elevations within the Little Blue River study reach for the May 28, 2020, high-flow event. 


\section{Conversion Factors}

U.S. customary units to International System of Units

\begin{tabular}{|c|c|c|}
\hline Multiply & By & To obtain \\
\hline \multicolumn{3}{|c|}{ Length } \\
\hline foot (ft) & 0.3048 & meter $(\mathrm{m})$ \\
\hline mile (mi) & 1.609 & kilometer (km) \\
\hline \multicolumn{3}{|c|}{ Area } \\
\hline square mile $\left(\mathrm{mi}^{2}\right)$ & 59.0 & hectare (ha) \\
\hline square mile $\left(\mathrm{mi}^{2}\right)$ & 2.590 & square kilometer $\left(\mathrm{km}^{2}\right)$ \\
\hline \multicolumn{3}{|c|}{ Volume } \\
\hline acre-foot (acre-ft) & & cubic meter $\left(\mathrm{m}^{3}\right)$ \\
\hline \multicolumn{3}{|c|}{ Flow rate } \\
\hline cubic foot per second $\left(\mathrm{ft}^{3} / \mathrm{s}\right)$ & 0.02832 & cubic meter per second $\left(\mathrm{m}^{3} / \mathrm{s}\right)$ \\
\hline $\begin{array}{l}\text { cubic foot per second per } \\
\text { square mile }\left(\left[\mathrm{ft}^{3} / \mathrm{s}\right] / \mathrm{mi}^{2}\right)\end{array}$ & 0.01093 & $\begin{array}{l}\text { cubic meter per second per } \\
\text { square kilometer }\left(\left[\mathrm{m}^{3} / \mathrm{s}\right] / \mathrm{km}^{2}\right)\end{array}$ \\
\hline \multicolumn{3}{|c|}{ Hydraulic gradient } \\
\hline foot per mile ( $\mathrm{ft} / \mathrm{mi}$ ) & 0.1894 & meter per kilometer $(\mathrm{m} / \mathrm{km})$ \\
\hline
\end{tabular}

International System of Units to U.S. customary units

\begin{tabular}{|c|c|c|}
\hline Multiply & By & To obtain \\
\hline \multicolumn{3}{|c|}{ Length } \\
\hline centimeter $(\mathrm{cm})$ & 0.3937 & inch (in.) \\
\hline meter (m) & 3.281 & foot (ft) \\
\hline meter (m) & 1.094 & yard (yd) \\
\hline
\end{tabular}

\section{Datum}

Vertical coordinate information is referenced to the North American Vertical Datum of 1988 (NAVD 88).

Horizontal coordinate information is referenced to the North American Datum of 1983 (NAD 83).

Elevation, as used in this report, refers to distance above the vertical datum. 


\section{Abbreviations}

\begin{tabular}{ll} 
AEP & annual exceedance probability \\
CN & Soil Conservation Service Curve Number \\
DEM & digital elevation model \\
FEMA & Federal Emergency Management Agency \\
FIS & flood-insurance study \\
GIS & geographic information system \\
HEC-GeoHMS & USACE Hydrologic Engineering Center-Geospatial Hydrologic \\
HEC-HMS & Modeling System \\
HEC-RAS & USACE Hydrologic Engineering Center-Hydrologic Modeling System \\
lidar & light detection and ranging \\
$n$-value & Manning's roughness coefficient \\
NLCD & National Land Cover Database \\
NSE & Nash-Sutcliffe efficiency \\
NWIS & National Water Information System \\
PBIAS & percentage bias \\
$R$ & storage coefficient \\
RMSE & root mean square error \\
$T C$ & time of concentration \\
USACE & U.S. Army Corps of Engineers \\
USGS & U.S. Geological Survey \\
$\infty$ & infinity \\
\hline
\end{tabular}




\title{
Precipitation-Driven Flood-Inundation Mapping of the Little Blue River at Grandview, Missouri
}

\author{
By David C. Heimann, Jonathon D. Voss, and Paul H. Rydlund, Jr.
}

\section{Abstract}

The U.S. Geological Survey (USGS), in cooperation with the City of Grandview, Missouri, assessed flooding of the Little Blue River at Grandview resulting from varying precipitation magnitudes and durations and expected land-cover changes. The precipitation scenarios were used to develop a library of flood-inundation maps that included a 3.5-mile reach of the Little Blue River and tributaries within and adjacent to the city.

A hydrologic model of the upper Little Blue River Basin and a hydraulic model of a selected study reach of the Little Blue River and tributaries were constructed to assess streamflow magnitudes associated with simulated precipitation amounts and the resulting flood-inundation conditions. The U.S. Army Corps of Engineers Hydrologic Engineering Center-Hydrologic Modeling System (HEC-HMS; version 4.4.1) was used to simulate the amount of streamflow produced from a range of rain events. The Hydrologic Engineering Center-River Analysis System (HEC-RAS; version 5.0.7) was then used to construct a steady-state hydraulic model to map resulting areas of flood inundation.

Both models were calibrated to the May 28, 2020, high-flow event that produced a peak streamflow approximating a 10-percent annual exceedance probability (10-year flood-frequency recurrence interval) at the Little Blue River at Grandview streamgage (USGS station 06893750). The calibrated HEC-HMS model was used to simulate streamflows from design rainfall events of 1- to 8-hour durations and ranging from a 100 - to 0.2 -percent annual exceedance probability. Flood-inundation maps were produced for USGS streamflow stages of 17.0 feet (ft), or near bankfull, to $23.0 \mathrm{ft}$, or a stage exceeding the 0.2 -percent annual exceedance interval flood, using the HEC-RAS model. The consequence of each precipitation duration-frequency value was represented by a 1 -ft increment inundation map based on the generated peak streamflow from that rainfall event and the corresponding stage at the reference USGS streamgage.

Four scenarios were developed with the HEC-HMS hydrologic model: (1) current (2016) land cover, normal antecedent soil-moisture conditions; (2) current land cover, wet antecedent soil-moisture conditions; (3) future land cover, normal antecedent soil-moisture conditions; and (4) future land cover, wet antecedent soil-moisture conditions. The future land-cover condition was estimated based on anticipated development in the basin. All precipitation scenarios were input into each of the four land-cover antecedent moisture conditions and then assigned to a resulting flood-inundation map based on the generated peak flow and corresponding stage at the reference streamgage.

\section{Introduction}

The city of Grandview, in the south Kansas City metropolitan area in west-central Missouri (fig. 1), had a population of about 24,900 in 2019 (U.S. Census Bureau, 2020). The city experienced moderate to major flooding from the Little Blue River and tributaries in July and August 2017, which resulted in an estimated \$4 million in damages to homes and infrastructure (KSHB News, 2019). Floodplains within Grandview generally are moderately to highly developed and contain a mix of residential and commercial structures. Before this study, emergency responders in Grandview relied on several information sources (all of which are publicly available) to make decisions on how to best alert the public and mitigate flood damages along the Little Blue River. One source is the Federal Emergency Management Agency (FEMA) floodinsurance study (FIS) for Jackson County, dated January 2017 (Federal Emergency Management Agency, 2017). A second source of information is the StormWatch (https://www.storm watch.com/) regional rainfall data network from which real-time precipitation data can be obtained and streamflow responses can be inferred. A third source of flood-related information is the National Weather Service issued watches, warnings, and advisories (https://www.weather.gov/).

In 2019, the U.S. Geological Survey (USGS), in cooperation with the City of Grandview, Missouri, began a project to develop a library of flood-inundation maps for a selected reach of the Little Blue River (fig. 2) and relate these maps to different rainfall frequencies and durations. As part of this study, a streamgage, Little Blue River at Grandview, Mo. (USGS station 06893750; U.S. Geological Survey, 2020c; table 1), and two precipitation-only gages, Eagles' Landing (USGS station 384950094330701; U.S. Geological Survey, 2020d; table 2) and Shalimar Park (USGS station 385035094304401; 


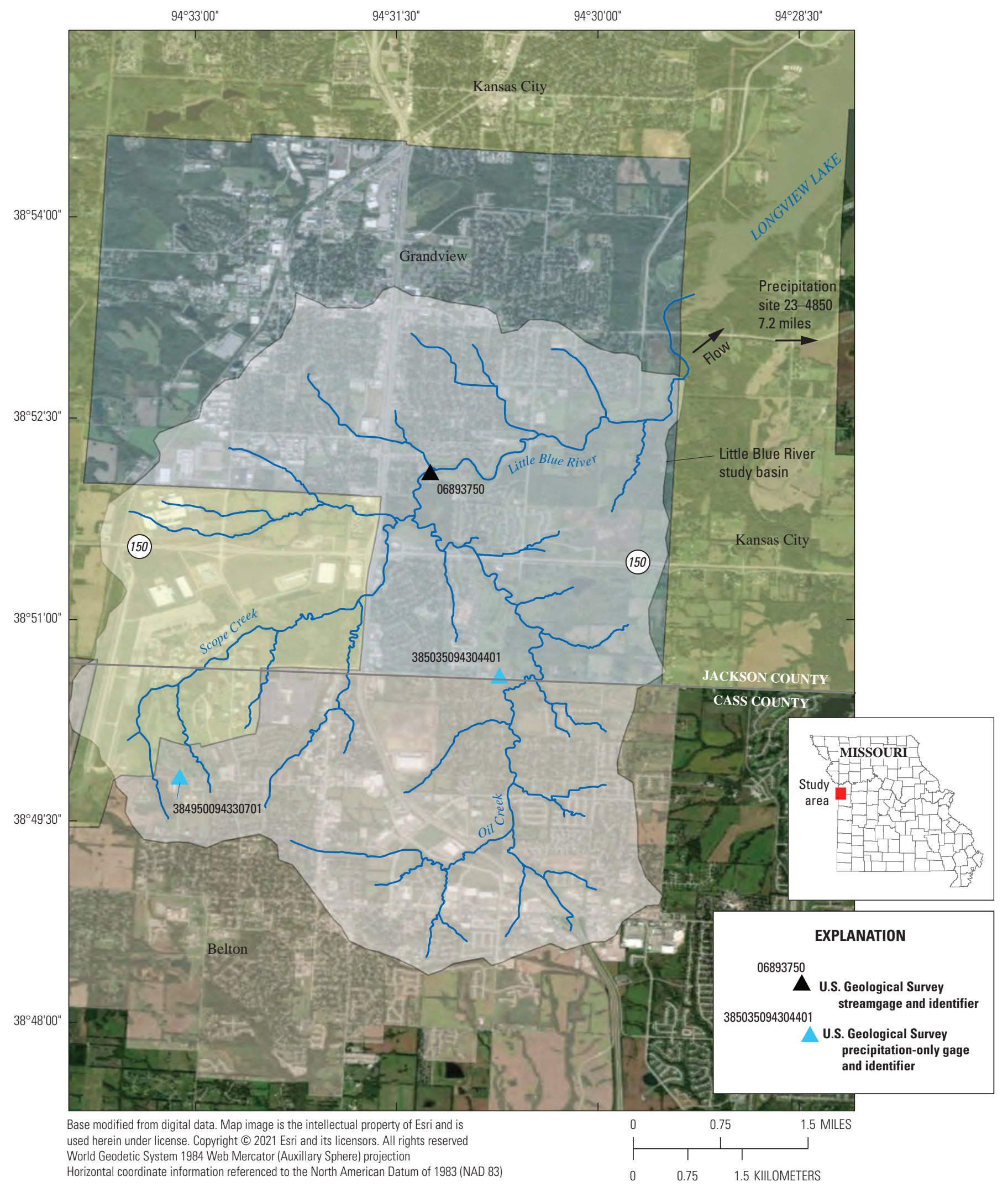

Figure 1. Location of city of Grandview and upper Little Blue River study basin. 


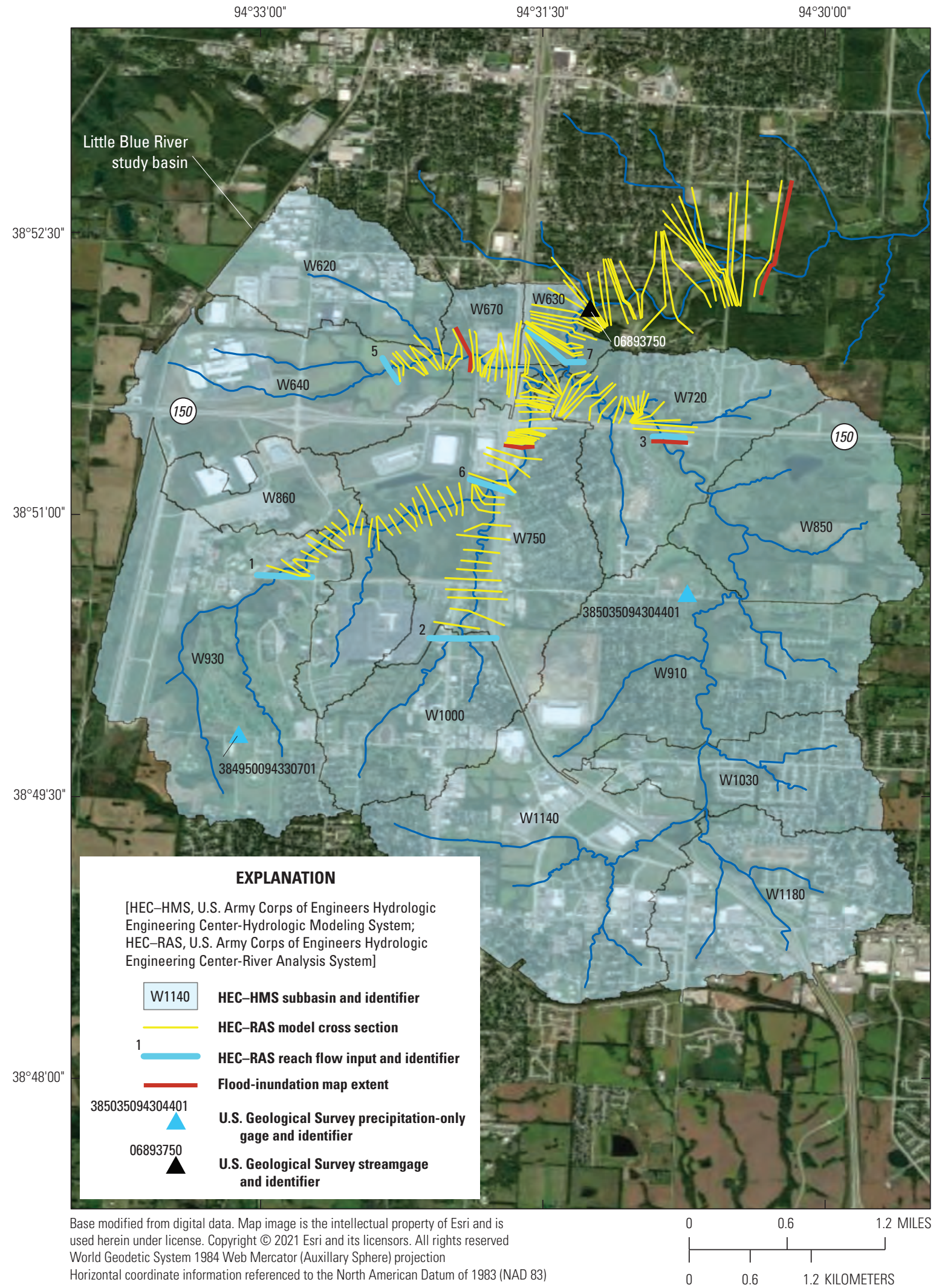

Figure 2. U.S. Army Corps of Engineers Hydrologic Engineering Center-Hydrologic Modeling System model basin and subbasins, Hydrologic Engineering Center-River Analysis System (HEC-RAS) model cross sections, HEC-RAS reach flow input locations, and extent of flood-inundation maps. 
Table 1. Description of U.S. Geological Survey streamgage at Little Blue River at Grandview, Missouri.

[Station location is shown in figure 1. Latitude and longitude are given in degrees $\left({ }^{\circ}\right)$, minutes $(')$, and seconds $\left({ }^{\prime \prime}\right)$. USGS, U.S. Geological Survey; mi², square mile; NAD 83, North American Datum of 1983; ft, foot; NAVD 88, North American Vertical Datum of 1988; ft³/s, cubic foot per second]

\begin{tabular}{cccccccc}
\hline $\begin{array}{c}\text { USGS } \\
\text { station name }\end{array}$ & $\begin{array}{c}\text { USGS } \\
\text { station } \\
\text { number }\end{array}$ & $\begin{array}{c}\text { Drainage } \\
\text { area } \\
\left(\mathbf{m i}^{2}\right)\end{array}$ & $\begin{array}{c}\text { Latitude } \\
\text { (NAD 83) }\end{array}$ & $\begin{array}{c}\text { Longitude } \\
\text { (NAD 83) }\end{array}$ & $\begin{array}{c}\text { Period of } \\
\text { peak-flow } \\
\text { record } \\
\text { (water year') }\end{array}$ & $\begin{array}{c}\text { Maximum recorded stage (ft), } \\
\text { corresponding streamgage } \\
\text { datum elevation } \\
\text { (ft, NAVD 88), and date }\end{array}$ & $\begin{array}{c}\text { Maximum } \\
\text { streamflow } \\
\text { (ft's/s) and date }\end{array}$ \\
\hline $\begin{array}{c}\text { Little Blue River } \\
\text { at Grandview, }\end{array}$ & 06893750 & 13.6 & $38^{\circ} 52^{\prime} 06^{\prime \prime}$ & $94^{\circ} 31^{\prime} 15^{\prime \prime}$ & $22019-21$ & $\begin{array}{c}18.03(929.46) \\
\text { May 28, 2020 }\end{array}$ \\
\begin{tabular}{l} 
Missouri \\
\hline
\end{tabular}
\end{tabular}

${ }^{1} \mathrm{~A}$ water year is the 12-month period from October 1 through September 30 of the following year and is designated by the calendar year in which it ends.

${ }^{2}$ Water year 2021 is incomplete, and current data period only was considered for maximum values.

Table 2. Description of U.S. Geological Survey precipitation-only gages in the Little Blue River study basin.

[Station location is shown in figure 1. Latitude and longitude are given in degrees $\left({ }^{\circ}\right)$, minutes $(')$, and seconds $\left({ }^{\prime \prime}\right)$. USGS, U.S. Geological Survey; NAD 83, North American Datum of 1983]

\begin{tabular}{|c|c|c|c|c|}
\hline USGS station name & USGS station number & $\begin{array}{l}\text { Latitude } \\
\text { (NAD 83) }\end{array}$ & $\begin{array}{l}\text { Longitude } \\
\text { (NAD 83) }\end{array}$ & $\begin{array}{l}\text { Period of record } \\
\text { (water year }{ }^{1} \text { ) }\end{array}$ \\
\hline Eagle’s Landing & 384950094330701 & $38^{\circ} 49^{\prime} 50^{\prime \prime}$ & $94^{\circ} 33^{\prime} 07^{\prime \prime}$ & $2020-21$ \\
\hline
\end{tabular}

${ }^{1} \mathrm{~A}$ water year is the 12-month period from October 1 through September 30 of the following year and is designated by the calendar year in which it ends.

U.S. Geological Survey, 2020e; table 2), were installed to provide stage, streamflow, and real-time precipitation data within the upper Little Blue River Basin. Although the current stage at a USGS streamgage is particularly useful for residents near a streamgage, it is of limited use to residents farther upstream or downstream because the water-surface elevation is not constant along the stream reach. Knowledge of a water level at a streamgage is difficult to translate into depth and areal extent of flooding at points distant from the streamgage. The small drainage area of the streamgage and small lead time of less than 3 hours (based on observed events) also provide limited advance notice to potential flood conditions. One way to address these informational gaps is to produce a library of flood-inundation maps that are based on precipitation amounts and durations and referenced to the stages recorded at the USGS streamgage. By referring to the appropriate map, emergency responders can discern the severity of flooding (depth of water and areal extent), identify roads that are or will soon be flooded, and make plans for notifying or evacuating residents in harm's way for some distance upstream and downstream from the streamgage. In addition, the capability to visualize the potential extent of flooding may motivate residents to take precautions and heed warnings that they previously might have disregarded.

\section{Purpose and Scope}

This report describes the development of a series of estimated flood-inundation maps for the Little Blue River at Grandview and identifies where on the internet the maps can be accessed and ancillary data (geographic information system [GIS] flood polygons and depth grids) can be downloaded. The study extent includes a 3.5-mile (mi) reach from $0.2 \mathrm{mi}$ upstream from Highway 150 to about $1.3 \mathrm{mi}$ downstream from the Little Blue River at Grandview streamgage (fig. 2). The maps were produced for flood levels using hydrologic data from the Little Blue River at Grandview streamgage (fig. 2, table 1) and simulated flood peaks from a range of precipitation probabilities and durations. The procedures applied in constructing the hydrologic and hydraulic models used to simulate flood-inundation scenarios with design rainfall events of 1- to 8-hour duration ranging from a 100- to a 0.2-percent annual exceedance probability (AEP) are described. Flood levels were referenced to the stage recorded at the Little Blue River at Grandview streamgage near the downstream extent of the study reach.

The flood-inundation maps of the Little Blue River cover stages ranging from 17.0 to 23.0 feet (ft), referenced to the Little Blue River at Grandview streamgage local datum. The $17.0-\mathrm{ft}$ stage is near bankfull. The $23.0-\mathrm{ft}$ stage exceeds the stage that corresponds to the estimated 0.2-percent AEP flood (500-year recurrence interval flood). 


\section{Study Area Description}

The Little Blue River is in west-central Missouri in the Wooded Osage Plains subdivision (U.S. Environmental Protection Agency, 2020) of the Central Irregular Plains ecoregion (Omernik, 1987). The study basin is characterized by gently rolling to moderately hilly topography with about $210 \mathrm{ft}$ of relief. The headwaters originate in Cass County, Mo., and the stream flows generally northeastward before entering Longview Lake (fig. 1). The drainage area at the Little Blue River at Grandview streamgage is 13.6 square miles ( $\mathrm{mi}^{2}$; table 1). Oil Creek and Scope Creek are tributaries forming the Little Blue River at their confluence downstream from Highway 150 and within the study reach (fig. 1). Based on cross-section survey data collected by USGS, the Little Blue River study reach has an average top-of-bank channel width of about $26 \mathrm{ft}$ and an average channel slope of 19.1 feet per mile.

Based on the 2016 National Land Cover Database (NLCD; Yang and others, 2018), about 72.1 percent of the land cover in the Little Blue River Basin upstream from the Little Blue River at Grandview streamgage was classified as developed, 20.8 percent was classified as grasslands and pasture, and 6.14 percent was classified as forest. As of July 2019, there are 13 structures in the study reach that cross the Little Blue River and tributaries.

\section{Previous Studies}

Probabilistic flood-inundation maps showing the extent of flood inundation previously were generated as part of the latest FIS for the Little Blue River and the city of Grandview (Federal Emergency Management Agency, 2017) completed by AMEC Environment and Infrastructure in March 2012. The FIS provides estimates of peak streamflows of 10-, 4-, 2-, 1-, and 0.2-percent AEPs and their associated water-surface elevations for the Little Blue River and selected tributaries.

\section{Creation of Flood-Inundation-Map Library}

The USGS has standardized the procedures for creating flood-inundation maps for flood-prone communities (U.S. Geological Survey, 2020a) so that the process followed and products produced are similar regardless of which USGS office is responsible for the work. Tasks specific to the development of the flood-inundation maps for this study included (1) developing and acquiring hydrologic and hydraulic models for the Little Blue River study reach; (2) surveying channel cross sections and bridges/culverts within the study reach; (3) calibrating time of concentration, time of storage, and recession parameters associated with the hydrologic model; (4) calibrating energy-loss factors (roughness coefficients) in the stream channel and floodplain associated with the hydraulic model; (5) determining steady-state flow data using the calibrated U.S. Army Corps of Engineers (USACE) Hydrologic Engineering Center-Hydrologic Modeling System (HEC-HMS) computer program (U.S. Army Corps of Engineers, 2020b) and probabilistic precipitation events; (6) computing water-surface profiles using the USACE Hydrologic Engineering Center-River Analysis System (HECRAS) computer program (U.S. Army Corps of Engineers, 2019); (7) producing estimated flood-inundation maps for selected stream stages using HEC-RAS and a GIS; and (8) preparing the maps as shapefile polygons that depict the areal extent of flood inundation at various stages and as depth grids that provide the depth of floodwaters shown on a USGS flood-inundation mapping application.

\section{Precipitation-Derived Streamflow}

Given the limited length of record from the Little Blue River at Grandview streamgage, a theoretical rating was developed using existing streamflow measurements and the calibrated HEC-RAS model. The Grandview streamgage is not a National Weather Service forecast point because of the small drainage area $\left(13.6 \mathrm{mi}^{2}\right)$ and the flashy hydrologic response of this basin. Flood stages at this location were, therefore, predicted from rainfall magnitudes and durations and generated flood hydrographs from a calibrated hydrologic model (HEC-HMS).

\section{Hydrologic Data}

This study uses hydrologic data from the USGS streamgage Little Blue River at Grandview (fig. 1, table 1) at which stage is measured every 5 minutes. The stages are transmitted every 15 minutes by a satellite radio and are made available on the internet through the USGS National Water Information System (NWIS) database (U.S. Geological Survey, 2020b). Stage data at this streamgage are referenced to a local datum but can be converted to water-surface elevations referenced to the North American Vertical Datum of 1988 (NAVD 88) by adding the vertical datum of $911.43 \mathrm{ft}$. Continuous records of streamflow for the Little Blue River streamgages are computed from a stage-streamflow relation (Turnipseed and Sauer, 2010). The streamflow records are available through the USGS NWIS database (U.S. Geological Survey, 2020b).

\section{Hydrologic Model Development}

A hydrologic model was used to simulate the peak streamflow for the Little Blue River Basin using design rainfall events covering a range of magnitudes and probabilities of exceedance. The hydrologic model was constructed using the USACE modeling system HEC-HMS (version 4.4.1; U.S. Army Corps of Engineers, 2020b). The HEC-HMS model was calibrated to the May 28, 2020, high-flow event 
recorded at the Little Blue River at Grandview streamgage. The calibrated HEC-HMS model was then used to simulate precipitation runoff from Atlas 14 rainfall amounts (National Oceanic and Atmospheric Administration, 2020) covering a range of 1 to 8 hours in duration and AEPs of 100 to 0.2 percent (Heimann and Voss, 2021). Output peak flows from the HEC-HMS model were then used as inputs for the hydraulic model (see "Hydraulic Model” section).

The HEC-HMS model was developed with the USACE Hydrologic Engineering Center-Geospatial Hydrologic Modeling System (HEC-GeoHMS) tool (version 10.2; U.S. Army Corps of Engineers, 2020a) and ArcHydro toolbox (version 10.2; Esri, 2021), which are GIS extensions. With the extensions, a 1-meter digital elevation model (DEM), a stream centerline, and 2016 NLCD impervious area datasets were used to delineate the $13.6-\mathrm{mi}^{2}$ drainage basin, define $14 \mathrm{sub}-$ basins (fig. 2), and define initial model parameters. The HECHMS model was run for single rainfall events (rather than as a continuous simulation), and subbasin components defined in the model included canopy, transformation, loss, and recession methods. The HEC-HMS model was then used to estimate streamflow input data at flow-change locations in the hydraulic model.

\section{Precipitation Data}

Accurate precipitation data are needed as input to the hydrologic model to simulate the resulting runoff and streamflow. Two precipitation-only gages were installed within the study basin, one in the Scope Creek Basin (Eagles' Landing, USGS station 384950094330701; fig. 2) and one in the Oil Creek Basin (Shalimar Park, USGS station 385035094304401; fig. 2) in the headwaters of the Little Blue River (fig. 1). Precipitation data also are available at the Little Blue River at Grandview streamgage. Precipitation totals at the precipitation-only gages are logged every 5 minutes and transmitted every 15 minutes by satellite radio, and all three gages have been in operation since October 2019. The observed precipitation for the May 28, 2020, high-flow event was used in calibrating the HEC-HMS model to this event. In the future, observed precipitation data from these gages can serve as an indicator of potential flooding. Precipitation totals corresponding to 1-, 2-, 3-, 4-, 6-, 12- and 24-hour durations can be set in the USGS WaterAlert system (U.S. Geological Survey, 2021) to notify users when target conditions have been met. The HEC-HMS simulations corresponding to selected precipitation event durations and magnitudes indicate the hydrologic response of the rainfall event and the appropriate flood-inundation map to reference.

Precipitation events used as input to the hydrologic model were developed from the National Oceanic and Atmospheric Administration Atlas 14 point-precipitation frequency estimates (National Oceanic and Atmospheric Administration, 2020) using the Lee's Summit (not shown), Mo., precipitation station (site identifier 23-4850, fig. 1). Selected values from the Atlas 14 table for Lee's Summit and additional interpolated values for durations of 4 and 8 hours are presented in a USGS data release (Heimann and Voss, 2021). The values for the 4- and 8-hour precipitation magnitudes were interpolated by fitting a line of best fit to the remaining 1-, 2-, 3-, and 6-hour duration values for each recurrence interval (fig. 3 ). The values represent a total amount for the specified duration. Time series of precipitation based on these totals were developed by distributing the precipitation in 5-minute increments over the specified duration using an alternating block distribution approach (Chow and others, 1988).

\section{Transformation Method}

Precipitation exceeding soil infiltration and storage is transformed into runoff in the developed HEC-HMS model using the Clark (1945) unit-hydrograph method. Two parameters needed to define this unit-hydrograph method are time of concentration (TC) and a storage coefficient (R). The TC is the time of travel (in hours) it takes for precipitation runoff to travel from the most distant point in a subbasin to the subba$\sin$ outlet. $\mathrm{R}$ is a storage coefficient (in hours) used to account for storage within the floodplain such as wetlands, reservoirs, and bridges that can produce flood-wave attenuation. Initial estimates of TC were calculated using the TR-55 methodology (Soil Conservation Service, 1986). R storage coefficient values were set to the initial Tc values for the subbasins and adjusted during model calibration.

\section{Loss Method}

The Soil Conservation Service Curve Number (CN) method was used to simulate precipitation losses. CN values were applied to each subbasin according to the TR-55 methodology (Soil Conservation Service, 1986), which uses hydrologic soil type, land use, land treatment, and antecedent runoff conditions. Composite CNs for each subbasin were determined through HEC-GeoHMS by developing a CN grid using soil spatial data from the Soil Survey Geographic Database (U.S. Department of Agriculture, 2020), land-cover information from the 2016 NLCD (Yang and others, 2018), and a lookup table of CN values corresponding to soil hydrologic classes and land use.

Using the Soil Conservation Service CN approach, antecedent runoff conditions are divided into three classes: $\mathrm{CN}(\mathrm{I})$ for dry soil conditions, $\mathrm{CN}$ (II) for average soil moisture conditions, and CN(III) for wet soil conditions (Natural Resources Conservation Service, 2004). Two antecedent soil moisture conditions were simulated in this study including average soil moisture $\mathrm{CN}(\mathrm{II})$ and wet antecedent conditions $\mathrm{CN}(\mathrm{III})$. 


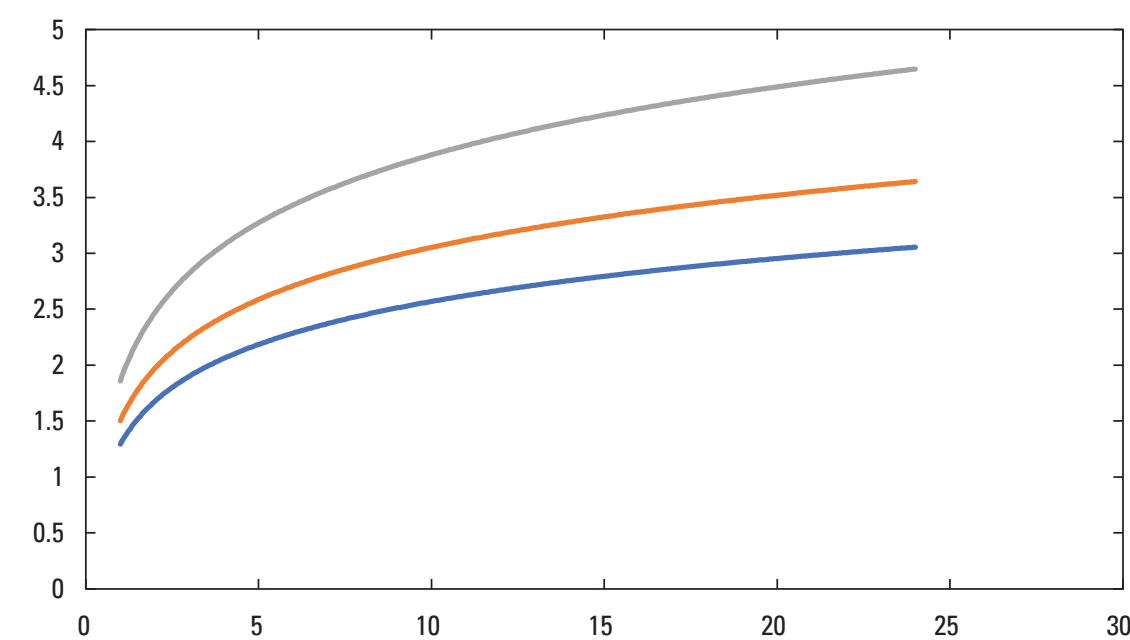

\section{EXPLANATION}

[In, natural logarithm]

Recurrence interval and corresponding formula defining relation between event duration and magnitude

5 year $-y=0.8776 \ln (x)+1.8593$

2 year $-y=0.6731 \ln (x)+1.5027$

1 year $-y=0.555 \ln (x)+1.2914$

\section{EXPLANATION}

[In, natural logarithm]

Recurrence interval and corresponding formula defining relation between event duration and magnitude

50 year $-y=1.5864 \ln (x)+2.8903$

25 year $-y=1.3498 \ln (x)+2.5664$

10 year $-y=1.0666 \ln (x)+2.1563$

\section{EXPLANATION}

[In, natural logarithm]

Recurrence interval and corresponding formula defining relation between event duration and magnitude

500 year $-y=2.5108 \ln (x)+3.9924$

200 year $-y=2.122 \ln (x)+3.5431$

100 year $-y=1.8391 \ln (x)+3.2158$

Figure 3. Relations between Atlas 14 precipitation totals and durations used in interpolating 4- and 8-hour precipitation totals for recurrence intervals of 1 to 500 years. 
Values of the initial average soil moisture condition values $\mathrm{CN}$ (II) used in the model were converted to wet conditions (CN[III]) using the following equation from Chow and others (1988):

$$
C N(\mathrm{III})=\frac{23 C N(\mathrm{II})}{10+0.13 C N(\mathrm{II})} .
$$

\section{Base-Flow Method}

The recession base-flow method (Chow and others, 1988) was used to simulate base flow within the basin. For this method, the HEC-HMS model requires three parameters: initial streamflow, a recession constant, and a ratio-to-peak constant. The initial streamflow was applied to the subbasin as a ratio of cubic feet per second per square mile. The recession constant represents the rate at which base flow recedes after a rainfall event. The ratio-to-peak constant is a threshold that indicates when to begin base flow on the recession limb of a hydrograph. These parameters were estimated and adjusted during the HEC-HMS model calibration.

\section{Channel Routing Method}

Channel routing and flood-wave attenuation were represented in the model using the Muskingum-Cunge routing method (Cunge, 1969). Input parameters applied to each model reach for this method included an initial flow condition, reach length, reach slope, channel and floodplain roughness (Manning's roughness coefficient [n-value]), and channel geometry characteristics.

\section{Hydrologic Model Calibration}

The hydrologic model was calibrated to the May 28, 2020, high-flow event, which is the largest flow measured at the streamgage since streamgage operation began in October 2019. The parameters TC, R, and base-flow recession were the primary parameters used in calibrating the simulated hydrograph peak and shape. Initial estimates of Tc and R were determined using the TR-55 methodology (Soil Conservation Service, 1986). The parameters initially were set to the same value and adjusted to match hydrograph shape, magnitude, and timing. Final calibration results indicated similarity in simulated and observed hydrographs (fig. 4). The Nash-Sutcliffe efficiency (NSE) coefficient and percentage bias (PBIAS) statistics were used to assess model fit (Nash and Sutcliffe, 1970). Values of NSE can vary from negative infinity $(-\infty)$ to 1 . Values of 1 correspond to a perfect match between simulated and observed time series whereas values less than 0 indicate the observed average is a better predictor than the simulated values. The NSE of the calibrated Little Blue River model was 0.98 , indicating that the simulated values were a good predictor of the observed hydrograph. The PBIAS (Gupta and others, 1999) is a measure of average tendency of the simulated data to be larger or smaller than observed values. Values of PBIAS can vary from $-\infty$ to $\infty$ with an optimum value of 0 . The calibrated model yielded a PBIAS value of 3.22, also indicating a good model fit. A comparison of relevant hydrograph characteristics also indicates similarities between simulated and observed peak streamflow, time of peak, and runoff volume (table 3).

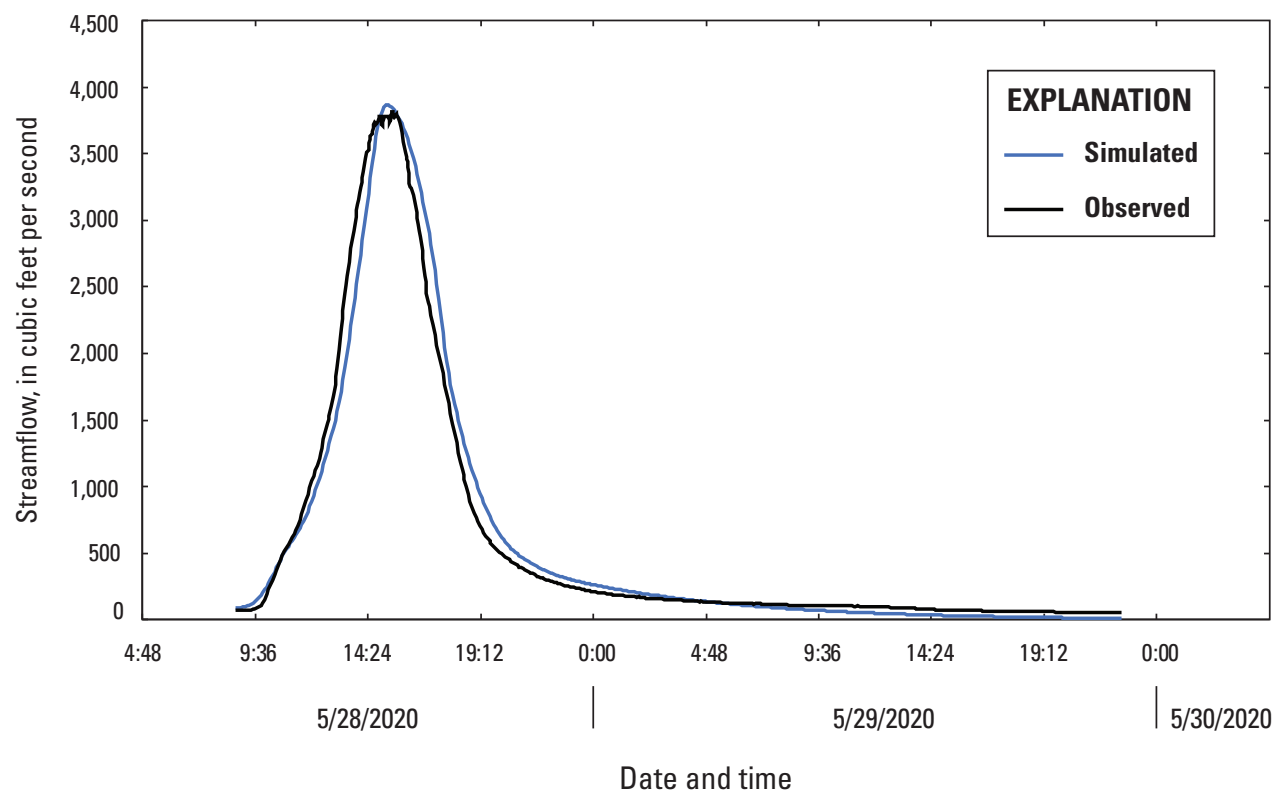

Figure 4. Simulated and observed streamflow hydrograph from the May 28, 2020, high-flow event at the Little Blue River at Grandview, Missouri, streamgage (U.S. Geological Survey streamgage, station 06893750). 
Table 3. Simulated and observed hydrograph characteristics of the May 28-29, 2020, high-flow event at the Little Blue River at Grandview, Missouri, streamgage (U.S. Geological Survey streamgage, station 06893750).

[ft $3 / \mathrm{s}$, cubic foot per second; hh:mm, hour and minute; acre-ft, acre foot]

\begin{tabular}{|c|c|c|c|c|c|c|c|c|}
\hline \multicolumn{3}{|c|}{$\begin{array}{l}\text { Peak streamflow } \\
\left(\mathrm{ft}^{3} / \mathrm{s}\right)\end{array}$} & \multicolumn{3}{|c|}{$\begin{array}{c}\text { Time of peak } \\
\text { (hh:mm) }\end{array}$} & \multicolumn{3}{|c|}{$\begin{array}{c}\text { Runoff volume } \\
\text { (acre-ft) }\end{array}$} \\
\hline Simulated & Observed & $\begin{array}{l}\text { Percentage } \\
\text { difference }\end{array}$ & Simulated & Observed & Difference & Simulated & Observed & $\begin{array}{l}\text { Percentage } \\
\text { difference }\end{array}$ \\
\hline 3,866 & 3,820 & 1.2 & $15: 15$ & $15: 25$ & $00: 10$ & 1,872 & 1,868 & 0.2 \\
\hline
\end{tabular}

\section{Hydrologic Model Scenarios}

Scenarios simulated using the hydrologic model were a current land cover, normal antecedent soil-moisture condition; a current land cover, wet antecedent soil-moisture condition; a future land cover, normal antecedent soil-moisture condition; and a future land cover, wet antecedent soil-moisture condition. The current land-cover information was obtained from the 2016 NLCD (fig. 5). The future land-cover information was obtained by modifying the 2016 NLCD information with anticipated areas of development (fig. 6) obtained from the City of Grandview (Dennis Randolf, City of Grandview, written commun., 2020). Each precipitation event provided in the "Precipitation Data" section was simulated using each of the four land-cover soil-condition scenarios. The resulting peak flows from each scenario that fell within the defined range of flows from bankfull to the stage exceeding the 0.2-percent AEP flow were assigned to a 1 - $\mathrm{ft}$ increment flood-inundation map (Heimann and Voss, 2021). The development of the flood-inundation maps is described in the following sections. The total range of stages produced from the precipitation scenarios was 14.98 to $23.41 \mathrm{ft}$ as referenced to the Little Blue River at Grandview streamgage. Flood-inundation maps were produced for 1-ft increments in stage ranging from near bankfull (17.0 ft) to the stage exceeding the estimated 0.2-percent AEP event (23.0 ft). Each precipitation scenario with a resulting stage between 16.50 and $23.41 \mathrm{ft}$ was then assigned to one of the 1-ft increment flood maps. Oil Creek and Scope Creek join to form the Little Blue River within the study reach along with flow additions from several minor tributaries and several flow-change locations corresponding to reach junctions that were included in the model to reflect tributary additions. Model reach input flows were obtained from HEC-HMS runs that produced resulting peak flows that were at or near the corresponding 1-ft stage increments represented by the floodinundation map (table 4).

\section{Computation of Water-Surface Profiles}

The hydraulic model used in this study was developed by the USGS using HEC-RAS (version 5.0.7; U.S. Army Corps of Engineers, 2019) and included a tributary model obtained from the FEMA mapping information platform (Federal
Emergency Management Agency, 2019). The combined model was calibrated by the USGS and used to produce the flood-inundation maps generated in this study. HEC-RAS is a one-dimensional model for simulating water-surface profiles with steady-state (gradually varied) or unsteady-state flow computation options.

\section{Topographic and Bathymetric Data}

All topographic data used in this study are referenced vertically to NAVD 88, unless otherwise stated, and horizontally to the North American Datum of 1983. The elevation data for cross sections were obtained from a DEM that was derived from several sources of light detection and ranging (lidar) data. Lidar data for the part of the Little Blue River study basin within the city limits of Kansas City, Mo., were collected in March 2018 by Kucera International and obtained from the City of Kansas City ${ }^{1}$ (James Walton, Kansas City Water Services Department, written commun., 2019). The postprocessing of these data was completed by Kucera International in September 2018. The DEM, covering the city limits of Kansas City and selected surrounding areas, was provided by the City of Kansas City ${ }^{1}$ (James Walton, Kansas City Water Services Department, written commun., 2019). As per USGS quality level 2 data-accuracy specifications (version 1.2; Heidemann, 2018), the lidar data required a nonvegetated vertical accuracy of a maximum 10-centimeter root mean square error (RMSE), and a vegetated vertical accuracy of a maximum 30 centimeters at the 95th percentile. The area within the basin outside of Kansas City was represented with 2006 lidar data from Jackson and Cass Counties and available through the Missouri lidar DEM download tool (Missouri Spatial Data Information Service, 2020). The 2006 lidar collection specifications included a vertical RMSE of less than $0.607 \mathrm{ft}$ at the 95-percent confidence level and a horizontal RMSE of less than $3.28 \mathrm{ft}$ at the 95 -percent confidence level. The vertical RMSE of the elevation data obtained from the topographic mapping data was $0.314 \mathrm{ft}$. The horizontal RMSE was $2.46 \mathrm{ft}$ or less. Lidar data obtained for Jackson and Cass Counties were collected by Sanborn Mapping Co. in April 2006, and

\footnotetext{
${ }^{1}$ At the time of publication, data were not publicly available from the City of Kansas City.
} 


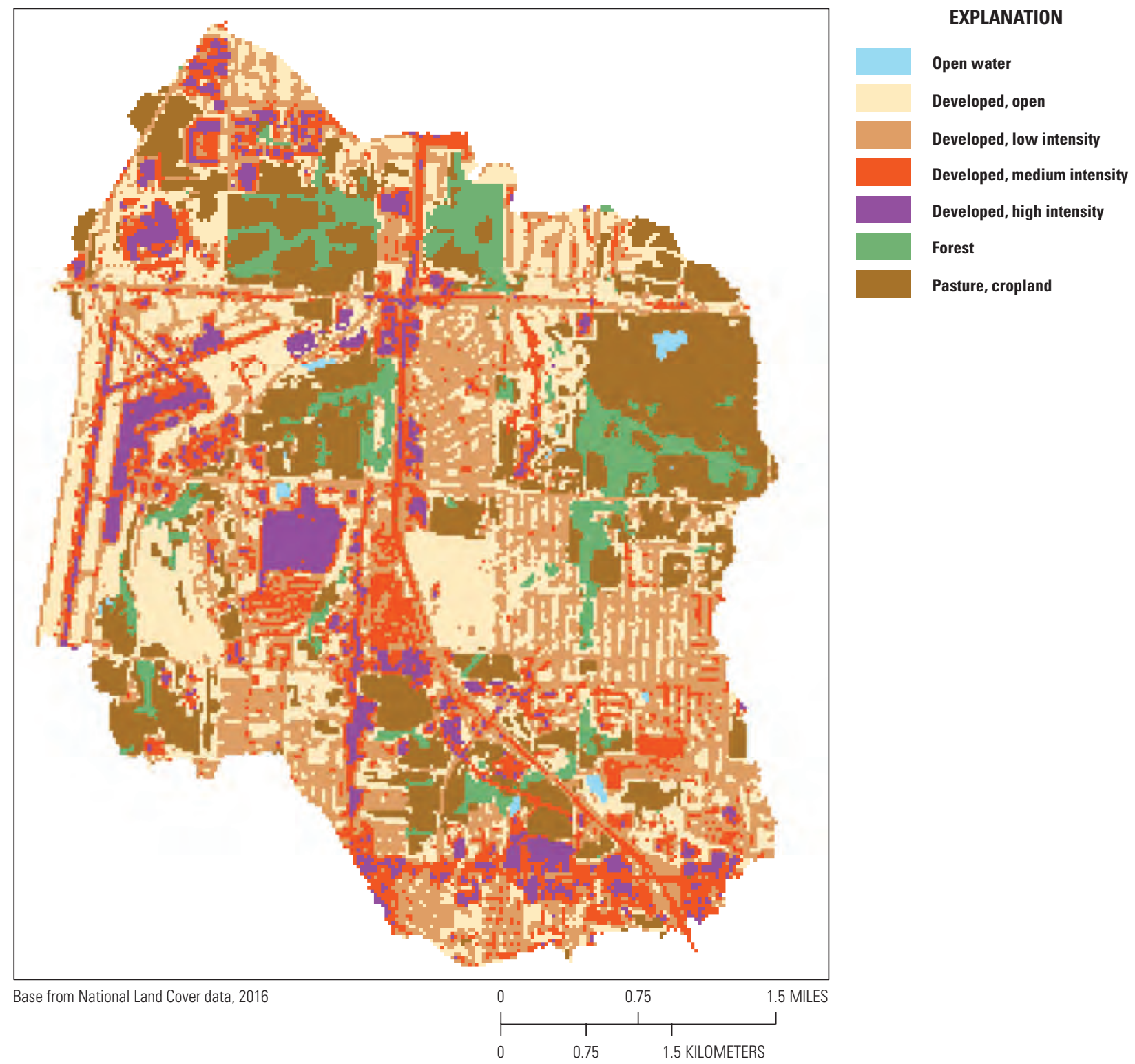

Figure 5. Simplified 2016 land-cover categories for the upper Little Blue River study basin (modified from Jin and others, 2019).

postprocessing was completed in August 2006. The final horizontal resolution of the combined lidar dataset was $4.0 \mathrm{ft}$. The accuracy specifications for all lidar datasets met or exceeded the U.S. National Map Accuracy Standards for vertical and horizontal accuracy guidelines for 2-ft contours (American Society for Photogrammetry and Remote Sensing, 1990, 2004).

Elevation data were extracted from the DEM for the model cross sections (fig. 2) using the RAS Mapper utility within HEC-RAS (U.S. Army Corps of Engineers, 2019). Because lidar data cannot provide ground elevations below the water surface of a stream, channel cross sections and bridge structures within the reach were surveyed by a USGS field crew in July 2020. Cross-sectional depths were measured by wading or taping down from a known bridge elevation. A differential global positioning system with real-time kinematic technology was used to derive vertical reference elevations at tape-down locations and to collect channel topographic elevation points. A level IV survey (Rydlund and Densmore, 2012) procedure was used in acquiring reference elevations with a resulting vertical accuracy of reference points within $0.32 \mathrm{ft}$. The bathymetric data were incorporated into the HEC-RAS model, and the RAS Mapper utility in HEC-RAS was used to generate a DEM of channel bathymetry and to merge the bathymetry DEM with the terrain DEM. 


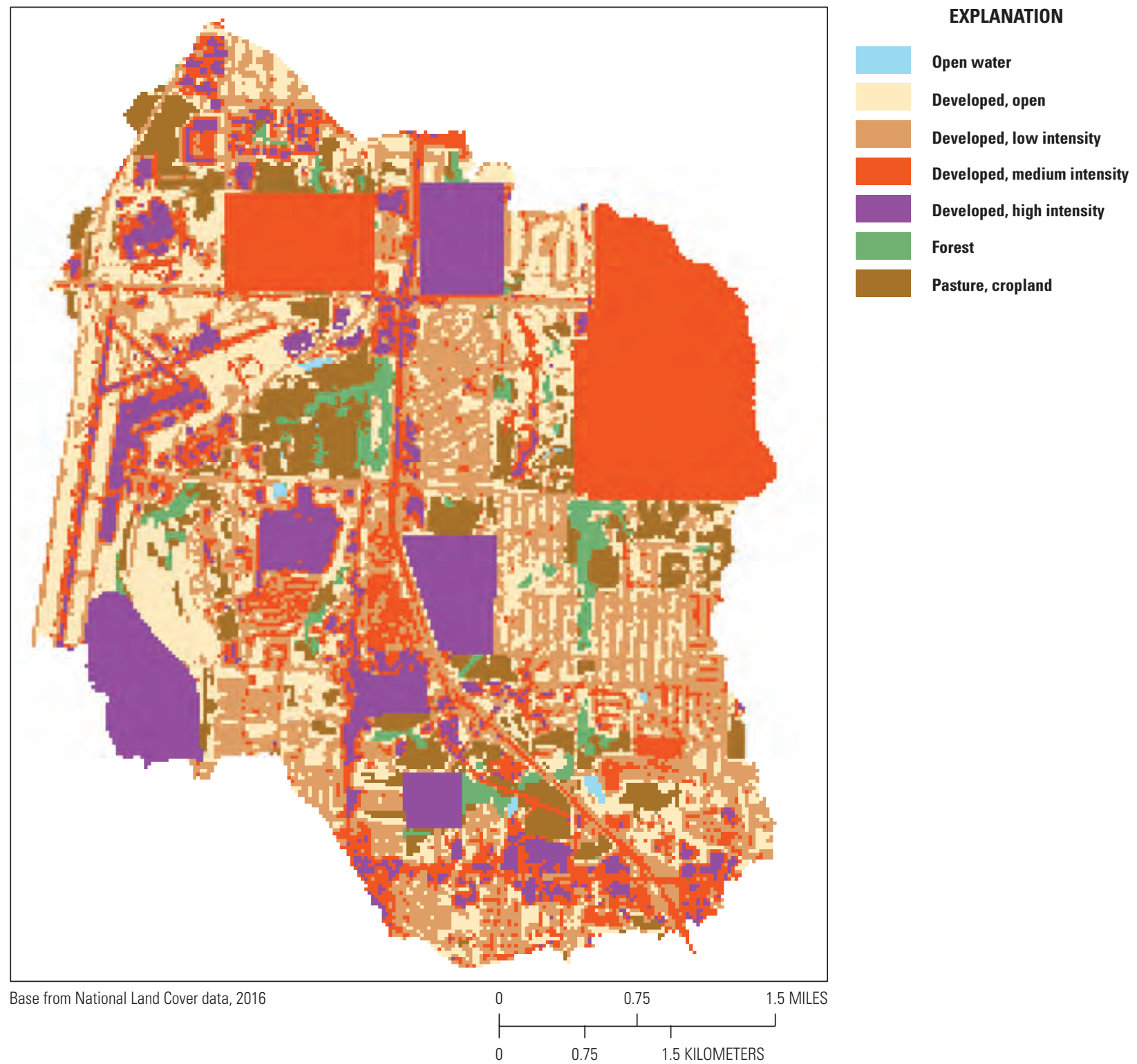

Figure 6. Simplified future land-cover categories for the upper Little Blue River study basin. [Source: Dennis Randolf, City of Grandview, written commun., 2020]

\section{Hydraulic Structures}

A total of 13 hydraulic structures are represented in the hydraulic model of the Little Blue River and tributaries, and have the potential to affect water-surface elevations during flooding along the stream. These 13 structures include 3 major four-lane highway bridges, 4 two-lane road bridges, 4 pedestrian bridges, and 2 culverts. Bridge-geometry data were obtained through field surveys by personnel from the USGS Central Midwest Water Science Center with the exception of two structures in reach 5 (fig. 2) that were included in the supplied tributary model obtained from FEMA (Federal Emergency Management Agency, 2019). All bridge-geometry information is contained in the hydraulic model used for analyses and provided in Voss and Heimann (2021).

\section{Energy-Loss Factors}

Hydraulic analyses require the estimation of energy losses that result from frictional resistance exerted by a channel on flow. These energy losses are quantified by the $n$-value. Initial (precalibration) $n$-values were selected on the basis of field observations, high-resolution aerial photographs collected through the U.S. Department of Agriculture National Agriculture Imagery Program and available through the Missouri Spatial Data Information Service (2019), and tabulated (Chow, 1959) and photographic estimates of $n$-values (Barnes, 1967).

As part of the calibration process, the initial $n$-values were varied by flow and adjusted until the differences between simulated and observed water-surface elevations at the 
Table 4. Estimated streamflows for corresponding stages and water-surface elevations at selected flow-change locations used in the hydraulic model of the Little Blue River at Grandview, Missouri.

[ft, foot; NAVD 88, North American Vertical Datum of 1988; ft³/s, cubic foot per second; CW, current land cover, wet antecedent soil-moisture scenario; CN, current land cover, normal antecedent soil-moisture scenario; FW, future land cover, wet antecedent soil-moisture scenario; FN, future land cover, normal antecedent soil-moisture scenario]

\begin{tabular}{|c|c|c|c|c|c|c|c|c|}
\hline \multirow{2}{*}{$\begin{array}{c}\text { Precipitation scenario } \\
\text { (table in Heimann and } \\
\text { Voss, 2021) }\end{array}$} & \multirow{2}{*}{$\begin{array}{l}\text { Stage of water- } \\
\text { surface profile } \\
(\mathrm{ft})^{2}\end{array}$} & \multirow{2}{*}{$\begin{array}{l}\text { Water-surface } \\
\text { elevation } \\
\text { (ft, NAVD 88) }\end{array}$} & \multicolumn{6}{|c|}{ Estimated streamflow at indicated location $\left(\mathrm{ft}^{3} / \mathrm{s}\right)$} \\
\hline & & & Reach 1 & Reach 2 & Reach 3 & Reach 5 & Reach 6 & Reach 7 \\
\hline 1 year, 3 hour, CW & 17 & 442.39 & 846 & 267 & 1,500 & 693 & 1,070 & 3,180 \\
\hline May 28, 2020, event & 318 & 443.39 & 1,000 & 300 & 1,600 & 640 & 1,250 & 3,820 \\
\hline 10 year, 4 hour, $\mathrm{CN}$ & 19 & 444.39 & 1,400 & 447 & 2,500 & 1,140 & 1,790 & 5,170 \\
\hline 10 year, 8 hour, FW & 20 & 445.39 & 1,920 & 555 & 3,370 & 1,550 & 2,430 & 7,310 \\
\hline 100 year, 4 hour, CN & 21 & 446.39 & 2,470 & 763 & 4,450 & 2,020 & 3,160 & 9,490 \\
\hline 200 year, 4 hour, FN & 22 & 447.39 & 3,030 & 876 & 5,390 & 2,510 & 3,790 & 11,900 \\
\hline 500 year, 8 hour, FN & 23 & 448.39 & 3,740 & 1,080 & 6,770 & 3,050 & 4,690 & 15,200 \\
\hline
\end{tabular}

1Table in Heimann and Voss (2021) is located in the "model_output" folder within the "LittleBlueRiver_Grandivew_HEC-HMS_model_archive.zip" file.

${ }^{2}$ Water-surface profiles are 1-ft increments of stage, referenced to the local streamgage datum of the U.S. Geological Survey streamgage 06893750, Little Blue River at Grandview, Missouri.

${ }^{3}$ The largest streamflow measurement corresponds to a stage of $18.03 \mathrm{ft}$.

streamgage and documented high-water marks along the study reach from the May 28, 2020, event were minimized. The final n-values ranged from 0.04 to 0.065 for the main channel and from 0.06 to 0.12 for the overbank areas simulated in this analysis. The lowest channel coefficients were placed in straight, downstream sections of the model reach, and the highest were placed in sinuous, higher gradient, coarse-material substrate tributary and headwater reaches with vegetated banks. The lowest roughness coefficients on the floodplain were placed in open grass areas and the highest in densely forested areas.

\section{Hydraulic Model}

The HEC-RAS analysis for this study was completed using the steady-state flow computation option. A onedimensional model with a steady-state flow option was used because the flow direction was primarily in the streamwise direction without substantial floodplain storage. Steady-state flow data consisted of flow regimes, boundary conditions, and peak flows that produced water-surface elevations at the streamgage cross sections that matched target water-surface elevations. These target elevations coincided with 1 - $\mathrm{ft}$ increments of stage, referenced to the local streamgage datum. Subcritical (tranquil) flow regime was assumed for the simulations. Normal depth, based on an estimated average watersurface slope of 0.004 , was used as the downstream boundary condition. The peak flows used in the HEC-RAS model are detailed in the "Hydrologic Data" section.

\section{Model Calibration}

The HEC-RAS model was calibrated to the peak streamgage reading and several high-water marks from the high-flow event on May 28, 2020. Model calibration was completed by adjusting $n$-values and ineffective flow characteristics until the results of the hydraulic computations closely agreed with the observed water-surface elevations for given flows. The difference between the observed and simulated water surface at the Little Blue River at Grandview streamgage was $-0.18 \mathrm{ft}$ (table 5 ). The differences between surveyed and simulated elevations of seven high-water marks in the study reach for the flood were less than or equal to $0.44 \mathrm{ft}$ (table 5). The results demonstrate that the model is capable of simulating accurate water levels throughout the reach.

\section{Model Validation}

The USGS precipitation-only gages and Little Blue River at Grandview streamgage were not in operation in 2017. The calibrated hydrologic and hydraulic models were validated using a nearby hourly precipitation station and a surveyed high-water mark from the August 21, 2017, flood. Hourly precipitation data from StormWatch precipitation site 2800, Prospect and Highway 150, on August 21, 2017, indicated 6.69 inches of precipitation fell over about 6 hours (https: //www.StormWatch.com). As documented in Heimann and Voss (2021), 6.69 inches of precipitation in 6 hours falls 
Table 5. Calibration of hydraulic model to target high-water elevations within the Little Blue River study reach for the May 28, 2020, high-flow event.

[ft, foot; NAVD 88, North American Vertical Datum of 1988; D, downstream side of bridge; U, upstream side of bridge]

\begin{tabular}{lccc}
\hline $\begin{array}{c}\text { Model reach identifier in figure 2 } \\
\text { (model station) }\end{array}$ & $\begin{array}{c}\text { Target water-surface elevation } \\
\text { (ft, NAVD 88) }\end{array}$ & $\begin{array}{c}\text { Simulated water-surface elevation } \\
\text { (ft, NAVD 88) }\end{array}$ & $\begin{array}{c}\text { Difference in elevation } \\
\text { (ft) }\end{array}$ \\
\hline 3 (4902.5 D) & 946.44 & 946.34 & -0.10 \\
3 (4902.5 D) & 946.38 & 946.34 & -0.03 \\
3 (4902.5 U) & 946.42 & 946.75 & 0.33 \\
6 (12178.5 U) & 940.30 & 939.95 & -0.35 \\
6 (12178.5 D) & 940.26 & 939.82 & -0.44 \\
7 (7097 D) streamgage & 929.46 & 929.28 & -0.18 \\
7 (1571.5 U) & 919.17 & 919.53 & 0.36 \\
7 (1571.5 D) & 919.07 & 919.35 & 0.28 \\
\hline
\end{tabular}

between a 100-year, 6-hour event value (6.34 inches) and a 200-year, 6-hour event value (7.13 inches). The predicted flood-inundation map stage for the 100-year, 6-hour and 200-year, 6-hour events is $22.0 \mathrm{ft}$ (table in Heimann and Voss, 2021; located in "model_output" folder within the "LittleBlueRiver_Grandivew_HEC-HMS_model_archive.zip" file). The water-surface elevation at a stage of $22.0 \mathrm{ft}$ at the Little Blue River at Grandview streamgage is $933.43 \mathrm{ft}$. A documented high-water mark near the streamgage from the August 21, 2017, flood had an elevation of $933.68 \mathrm{ft}$, indicating close agreement.

\section{Development of Water-Surface Profiles}

The calibrated hydraulic model was used to generate water-surface profiles for a total of seven stages at 1 -ft intervals between 17.0 and $23.0 \mathrm{ft}$, as referenced to the local datum of the Little Blue River at Grandview streamgage. These stages correspond to elevations of 928.43 and $934.43 \mathrm{ft}$ above NAVD 88, respectively. A rating curve for the Little Blue River at Grandview is in development, so an interim theoretical rating was developed using streamflow measurements and incremental flows to develop a stage-streamflow rating using the HEC-RAS model with a normal-depth downstream boundary condition. Streamflows through the study reach were adjusted for tributary inflows by including several flow-change locations (fig. 2, table 3) in the model to represent the cumulative addition of primary tributary inflows. Input flows for the flow-change location were estimated using the HEC-HMS model for the flows nearest the target 1-ft increment stages.

\section{Development of Flood-Inundation Maps}

Flood-inundation maps were created for the Little Blue River study reach and referenced to the Little Blue River at Grandview streamgage. The DEM data were derived from the same lidar data described in the "Topographic and Bathymetric Data” section and, therefore, have an estimated vertical accuracy of $2 \mathrm{ft}$ (that is, plus or minus $1 \mathrm{ft}$ ). Estimated flood-inundation boundaries and depth grids for each simulated profile were developed with the HEC-RAS mapper and exported from HEC-RAS (Voss and Heimann, 2021). Shapefile polygons and depth grids of the inundated areas for each profile were modified, as needed, in the ArcMap (version 10.7.1) application of ArcGIS Pro (Esri, 2021) to ensure a hydraulically reasonable transition of the flood boundaries between modeled cross sections.

Any inundated areas that were detached from the main channel were examined to identify subsurface connections with the main river, such as through culverts under roadways. Where such connections existed, the mapped inundated areas were retained in their respective flood maps; otherwise, the erroneously delineated parts of the flood extent were deleted. The flood-inundation areas are overlaid on high-resolution, georeferenced, aerial photographs of the study area. Bridge surfaces are shown as not inundated until the lowest flood stage exceeds the elevation of the bridge deck, in which case the bridge surface is depicted as being inundated. Estimates of water depth can be obtained from the depth-grid data that are included with the presentation of the flood maps on an interactive USGS mapping application described in the "FloodInundation Map Delivery" section. The flood map corresponding to the highest simulated water-surface profile, a stage of $23.0 \mathrm{ft}$, is shown in figure 7 .

\section{Flood-Inundation Map Delivery}

The seven developed flood-inundation polygons and corresponding depth grids (prior to GIS processing) are available at Voss and Heimann (2021). Also, a Flood Inundation Mapping Program website (U.S. Geological Survey, 2020a) has been established to make fully processed USGS 


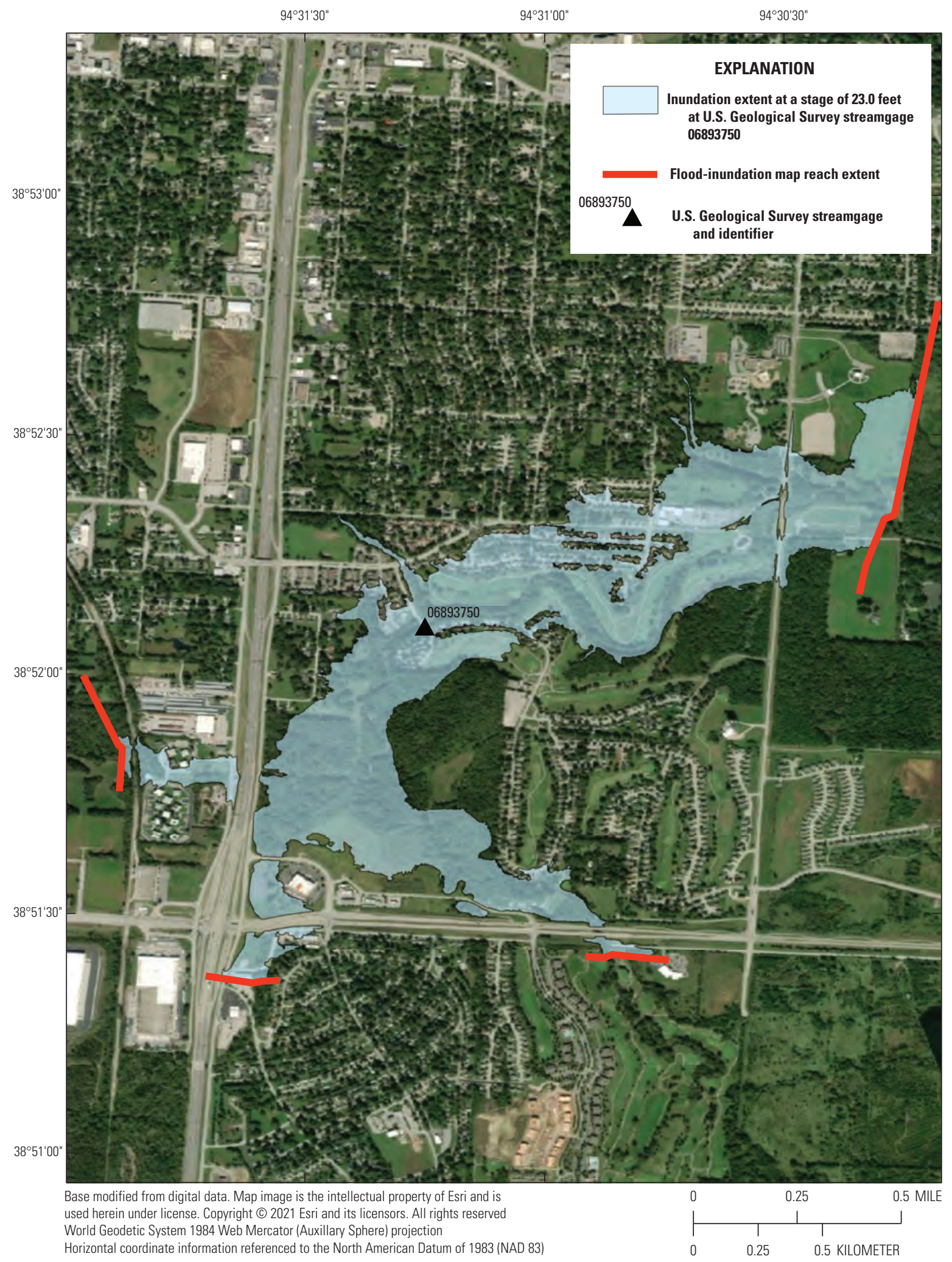

Figure 7. Flood-inundation map for the Little Blue River at Grandview, Missouri, study reach corresponding to a stage of 23.0 feet at the U.S. Geological Survey streamgage 06893750. 
flood-inundation study information available to the public. The website links to a mapping application that presents map libraries and provides detailed information on flood extents and depths for modeled sites. The mapping application enables the production of customized flood-inundation maps from the map libraries for the Little Blue River. A link on the mapping application website connects to the USGS NWIS database (U.S. Geological Survey, 2020a), which provides the current stage and streamflow at the Little Blue River at Grandview streamgage, to which the inundation maps are referenced. Additionally, a link is provided on the mapping application to the USGS WaterAlert application (U.S. Geological Survey, 2021), which notifies the user when a specified precipitation threshold is reached.
The determination of the appropriate flood-inundation map to reference for a particular event begins with the monitoring of precipitation (fig. 8). The user can sign up for USGS WaterAlert (U.S. Geological Survey, 2021) notifications for precipitation durations of 1, 2, 3, 4, and 6 hours using the link provided with the USGS station 384950094330701 and 385035094304401 precipitation totals in NWIS (U.S. Geological Survey, 2020d, e). The WaterAlert application notifies the user when a user-specified precipitation threshold (this can be determined using data from Heimann and Voss [2021]) has been exceeded. The notification provides the minimum expected response as a result of current accumulated precipitation. If precipitation continues, then the user updates the accumulation total and duration using additional WaterAlert notifications or totals from station updates

Sign up for 1-, 2-, 3-, 4-, and 6-hour WaterAlerts at U.S. Geological Survey precipitation stations 384950094330701 and 385035094304401 using threshold precipitation magnitude values from summary table of precipitation and responses in Heimann and Voss (2021); located in the "model_output" folder within the "LittleBlueRiver_HEC-HMS_model_archive.zip" file.

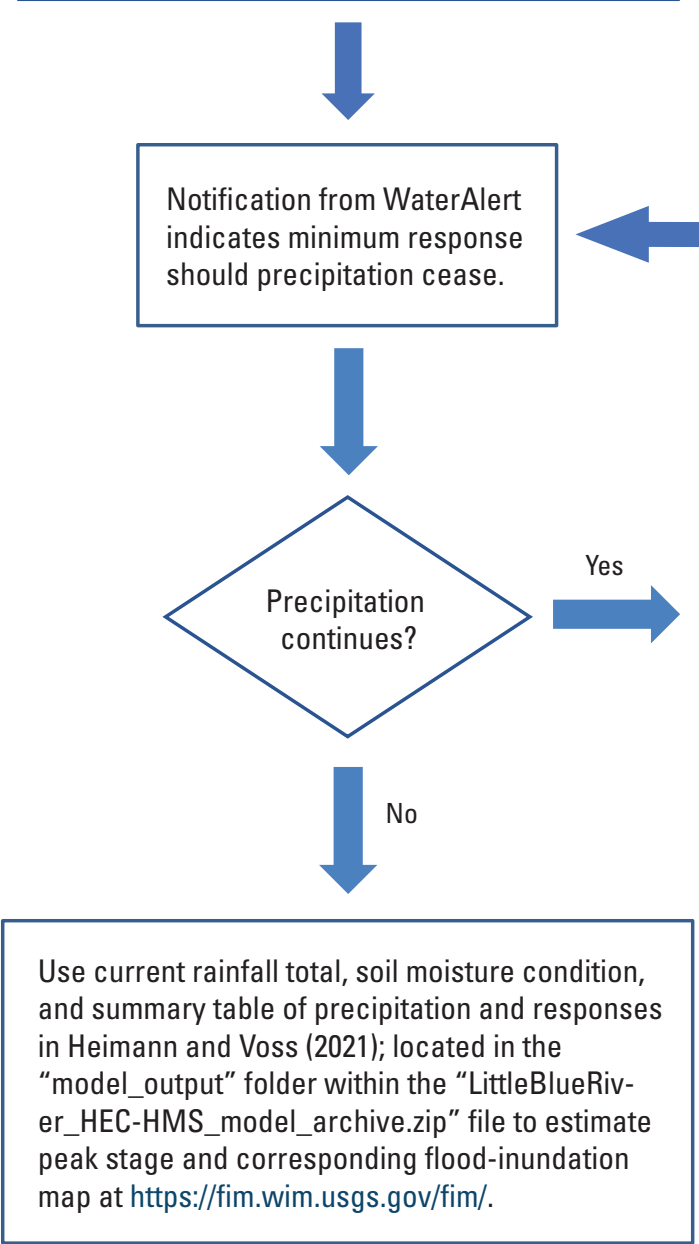

Monitor precipitation and update accumulation total and duration with continued WaterAlert notifications and observed precipitation gage values.
Figure 8. Decision process in determining the hydrologic response, including estimated stage and corresponding flood-inundation map, from observed accumulated precipitation. 
provided in NWIS (U.S. Geological Survey, 2020d, e). By tracking the 15-minute precipitation updates and WaterAlert notifications, the user can continue updating the expected response and the corresponding flood-inundation map.

The estimated flood-inundation maps are shown in sufficient detail so that preparations for flooding and decisions for emergency response could be completed efficiently. Depending on the flood magnitude, roadways are shown as shaded (inundated and likely impassable) or not shaded (dry and passable) to facilitate emergency planning and use. Bridges are shaded - that is, shown as inundated - when the flood stage exceeds the elevation of the bridge deck. A shaded building should not be interpreted to mean that the structure is completely submerged but, rather, that bare earth surfaces near the building are inundated. In these instances, the water depth (as indicated in the mapping application by holding the cursor over an inundated area) near the building would be an estimate of the water level inside the structure, unless flood-proofing measures had been implemented.

\section{Disclaimer for Flood-Inundation Maps}

The flood-inundation maps should not be used for navigation, regulatory, permitting, or other legal purposes. The USGS provides these maps "as is" for a quick reference emergency planning tool but assumes no legal liability or responsibility resulting from the use of this information.

\section{Uncertainties and Limitations Regarding Use of Flood-Inundation Maps}

Although the flood-inundation maps represent the boundaries of inundated areas with a distinct line, some uncertainty is associated with these maps. The flood boundaries shown were estimated based on water stages and streamflows at a selected USGS streamgage. Water-surface elevations along the stream reach were estimated by steady-state hydraulic modeling, assuming unobstructed flow, and used streamflows and hydrologic conditions anticipated at the Little Blue River at Grandview streamgage. The hydraulic model reflects the land-cover characteristics and any bridge, dam, levee, or other hydraulic structures existing as of September 2019. Unique meteorological factors (timing and distribution of precipitation) may cause actual streamflows along the modeled reach to vary from those assumed during a flood, which may lead to deviations in the water-surface elevations and inundation boundaries shown. Additional areas may be flooded because of unanticipated conditions such as changes in the streambed elevation or roughness, backwater into major tributaries along a river main-stem, or backwater from localized debris or ice jams. The accuracy of the floodwater extent portrayed on these maps will vary with the accuracy of the DEM used to simulate the land surface. Of the seven flood-inundation model scenarios, five exceed the largest streamflow measurement made at the Little Blue River at Grandview streamgage corresponding to a stage of about $18 \mathrm{ft}$; therefore, there is additional uncertainty for flood-inundation maps at stages greater than $18 \mathrm{ft}$.

The user also should be aware of additional uncertainties that may be inherent or factored into the simulation of flood peaks using rainfall-runoff simulations. A hydrologic model was used to simulate flood peaks associated with various probabilistic precipitation amounts. The precipitation was assumed to follow a defined temporal distribution over the duration of the event and an even spatial distribution over the basin. The actual temporal and spatial distribution of precipitation may vary, thereby affecting the timing and magnitude of the predicted flood peak. A single "simple" storm was simulated with near base-flow starting conditions. In the case of multiple compounding precipitation events, the user should take into consideration the starting streamflow when selecting the appropriate inundation map. Another source of uncertainty will arise from a precipitation event on frozen ground or on a substantial existing snowpack, both of which were not included in simulations and may affect the timing and magnitude of the predicted flood peak.

\section{Summary}

A series of seven digital flood-inundation maps were developed by the U.S. Geological Survey (USGS), in cooperation with the City of Grandview, Missouri, for a 3.5-mile reach of the Little Blue River at Grandview, Mo. The maps were developed using the U.S. Army Corps of Engineers Hydrologic Engineering Center-River Analysis System (version 5.0.7) and input streamflows derived from precipitation values of 1- to 500-year recurrence intervals and the Hydrologic Engineering Center-Hydrologic Modeling System (version 4.4.1). Computed water-surface profiles delineate estimated flood-inundation areas and depths of flooding resulting from various precipitation magnitudes and durations. The Hydrologic Engineering Center-River Analysis System hydraulic model and Hydrologic Engineering Center-Hydrologic Modeling System hydrologic models were calibrated to discrete streamflow measurements from the Little Blue River at Grandview streamgage (USGS station 06893750). The model encompassing the study reach was used to compute seven water-surface profiles for flood stages at 1-foot (ft) intervals referenced to the local streamgage datum and ranging from $17.0 \mathrm{ft}$, or near bankfull, to $23.0 \mathrm{ft}$, which exceeds the stage corresponding to the estimated 0.2 -percent annual exceedance probability flood (500-year recurrence interval).

Four scenarios were developed with the Hydrologic Engineering Center-Hydrologic Modeling System hydrologic model: (1) current (2016) land cover, normal antecedent 
soil-moisture conditions; (2) current land cover, wet antecedent soil-moisture conditions; (3) future land cover, normal antecedent soil-moisture conditions; and (4) future land cover, wet antecedent soil-moisture conditions. The future land-cover condition was estimated based on anticipated development in the basin. All precipitation scenarios were input into each of the four land-cover antecedent moisture conditions and then assigned to a resulting flood-inundation map based on the generated peak flow and corresponding stage at the reference streamgage.

The simulated water-surface profiles were then combined with a geographic information system digital elevation model derived from light detection and ranging data to delineate estimated flood-inundation areas as shapefile polygons and depth grids for each profile. These flood-inundation polygons were overlaid on high-resolution, georeferenced aerial photographs of the study area. The flood maps are available through a mapping application that can be accessed on the USGS Flood Inundation Mapping Program website (https://www.usgs.gov/mission-areas/water-resources/science/ flood-inundation-mapping-fim-program).

Interactive use of the maps on this mapping application can give users a general indication of the depth of water at any point by using the mouse cursor to click within the shaded areas. These maps are used in conjunction with the real-time stage data from the Little Blue River at Grandview reference streamgage. The joint products could help guide the public in taking individual safety precautions and provide emergencymanagement personnel with a tool to mitigate and prepare for flood-related emergencies, efficiently manage emergency flood operations, and effectively complete postflood recovery efforts.

\section{References Cited}

American Society for Photogrammetry and Remote Sensing, 1990, ASPRS accuracy standards for large-scale maps: American Society for Photogrammetry and Remote Sensing, 3 p., accessed December 17, 2018, at http://www. asprs.org/a/society/committees/standards/1990_jul_10681070.pdf.

American Society for Photogrammetry and Remote Sensing, 2004, ASPRS guidelines-Vertical accuracy reporting for lidar data: American Society for Photogrammetry and Remote Sensing, 20 p., accessed December 17, 2018, at https://www.asprs.org/a/society/committees/standards/ Vertical_Accuracy_Reporting_for_Lidar_Data.pdf.

Barnes, H.H., Jr., 1967, Roughness characteristics of natural channels: U.S. Geological Survey Water-Supply Paper 1849, 219 p. [Also available at https://doi.org/10.3133/ wsp1849.]

Chow, V.T., 1959, Open-channel hydraulics: New York, McGraw-Hill, 680 p.
Chow, V.T., Maidment, D.R., and Mays, L.W., Jr., 1988, Applied hydrology: New York, McGraw-Hill Book Company, $572 \mathrm{p}$.

Clark, C.O., 1945, Storage and the unit hydrograph: Transactions of the American Society of Civil Engineers, v. 110 , no. 1, p. 1419-1446.

Cunge, J.A., 1969, On the subject of a flood propagation method (Muskingum method): Journal of Hydraulic Research, v. 7, no. 2, p. 205-230. [Also available at https://doi.org/10.1080/00221686909500264.]

Esri, 2021, Arc Hydro (version 10.2): Esri software release, accessed February 12, 2020, at https://community.esri.com/ t5/water-resources-questions/arc-hydro-installationversions-and-documentation/m-p/269522.

Federal Emergency Management Agency, 2017, Flood insurance study, Jackson County, Missouri, and incorporated areas and Kansas City: Washington, D.C., Federal Emergency Management Agency, v. 1, 117 p. [Also available at https://map1.msc.fema.gov/data/29/S/PDF/ 29095CV001B.pdf?LOC=3b8040a98c0a56dd89a20d 3bc7cb5a10.]

Federal Emergency Management Agency, 2019, Mapping information platform: Federal Emergency Management Agency web page, accessed June 8, 2020, at https://hazards .fema.gov/femaportal/wps/portal.

Gupta, H.V., Sorooshian, S., and Yapo, P.O., 1999, Status of automatic calibration for hydrologic models-Comparison with multilevel expert calibration: Journal of Hydrologic Engineering, v. 4, no. 2, p. 135-143. [Also available at https://doi.org/10.1061/(ASCE)1084-0699(1999)4:2(135).]

Heidemann, H.K., 2018, Lidar base specification (ver. 1.3, February 2018): U.S. Geological Survey Techniques and Methods, book 11, chap. B4, 101 p., accessed February 7, 2020, at https://doi.org/10.3133/tm11b4.

Heimann, D.C., and Voss, J.D., 2021, Archive of hydrologic models used to generate flood peaks based on selected precipitation durations and recurrence intervals for the Little Blue River Basin, Grandview, Missouri: U.S. Geological Survey data release, https://doi.org/10.5066/P9G68JQQ.

Jin, S., Homer, C.G., Yang, L., Danielson, P., Dewitz, J., Li, C., Zhu, Z., Xian, G., and Howard, D., 2019, Overall methodology design for the United States National Land Cover Database 2016 products: Remote Sensing, v. 11, no. 24, art. 2971, 32 p. [Also available at https://doi.org/10.3390/ rs11242971.]

KSHB News, 2019, Amid continued heavy rainfall, Grandview monitors flood-prone areas: accessed December 2020 at https://www.kshb.com/news/local-news/ amid-continued-heavy-rainfall-grandview-monitors-floodprone-areas. 
Missouri Spatial Data Information Service, 2019, Missouri imagery data: Missouri Spatial Data Information Service digital data, accessed September 14, 2019, at https://www .msdis.missouri.edu/data/imagery/index.html. [National Agriculture Imagery Program 2018 data directly accessible at https://msdis-archive.missouri.edu/archive/Missouri_ Imagery/naip2018/.]

Missouri Spatial Data Information Service, 2020, Missouri LiDAR DEM download tool: Missouri Spatial Data Information Service digital data, accessed January 4, 2020, at https://msdis.maps.arcgis.com/apps/View/index.html? appid=350bcb69dfb74ca58aae74a32728f58b.

Nash, J.E., and Sutcliffe, J.V., 1970, River flow forecasting through conceptual models part 1-A discussion of principles: Journal of Hydrology (Amsterdam), v. 10, no. 3, p. 282-290. [Also available at https://doi.org/10.1016/00221694(70)90255-6.]

National Oceanic and Atmospheric Administration, 2020, NOAA Atlas 14-Point precipitation frequency estimatesMO: National Oceanic and Atmospheric Administration digital data, accessed March 2020 at https://hdsc.nws .noaa.gov/hdsc/pfds/pfds_map_cont.html?bkmrk=mo.

Natural Resources Conservation Service, 2004, Estimation of direct runoff from storm rainfall-Part 630 hydrologyNational engineering handbook: Washington, D.C., U.S. Department of Agriculture, 22 p. [Also available at https: //directives.sc.egov.usda.gov/17752.wba.]

Omernik, J.M., 1987, Ecoregions of the conterminous United States: Annals of the Association of American Geographers, v. 77, no. 1, p. 118-125. [Also available at https://doi.org/ 10.1111/j.1467-8306.1987.tb00149.x.]

Rydlund, P.H., Jr., and Densmore, B.K., 2012, Methods of practice and guidelines for using survey-grade global navigation satellite systems (GNSS) to establish vertical datum in the United States Geological Survey: U.S. Geological Survey Techniques and Methods, book 11, chap. D1, 102 p. with appendixes. [Also available at https://doi.org/ 10.3133/tm11D1.]

Soil Conservation Service, 1986, Urban hydrology for small watersheds-TR 55: Washington, D.C., U.S. Department of Agriculture, 98 p. [Also available at https: //www.nrcs.usda.gov/Internet/FSE_DOCUMENTS/ stelprdb1044171.pdf.]

Turnipseed, D.P., and Sauer, V.B., 2010, Discharge measurements at gaging stations: U.S. Geological Survey Techniques and Methods, book 3, chap. A8, 87 p. [Also available at https://doi.org/10.3133/tm3A8.]
U.S. Army Corps of Engineers, 2019, HEC-RAS-River analysis system-Hydraulic reference manual (ver. 5.0.7, March 2019): U.S. Army Corps of Engineers, [variously paged], accessed May 15, 2019, at https://www.hec.usace .army.mil/software/hec-ras/download.aspx.

U.S. Army Corps of Engineers, 2020a, Hydrologic Engineering Center (HEC-GeoHMS 10.2): U.S. Army Corps of Engineers software release, accessed February 22, 2020, at https://www.hec.usace.army.mil/software/hecgeohms/downloads.aspx.

U.S. Army Corps of Engineers, 2020b, Hydrologic Engineering Center (HEC-HMS 4.4.1): U.S. Army Corps of Engineers software release, accessed February 22, 2020, at https://www.hec.usace.army.mil/software/hec-hms/ downloads.aspx.

U.S. Census Bureau, 2020, QuickFacts-Grandview Missouri: U.S. Census Bureau digital data, accessed December 2020 at https://www.census.gov/quickfacts/grandviewci tymissouri.

U.S. Department of Agriculture, 2020, Geospatial Data Gateway: U.S. Department of Agriculture web page, accessed March 8, 2020, at https://datagateway.nrcs .usda.gov/.

U.S. Environmental Protection Agency, 2020, Level III and IV ecoregions by EPA region: U.S. Environmental Protection Agency digital data, accessed December 2020 at https://www.epa.gov/eco-research/level-iii-and-ivecoregions-epa-region.

U.S. Geological Survey, 2020a, Flood Inundation Mapping (FIM) Program: U.S. Geological Survey web page, accessed January 7, 2020, at https://www.usgs.gov/ mission-areas/water-resources/science/flood-inundationmapping-fim-program?qt-science_center_objects $=0 \#$ qtscience_center_objects.

U.S. Geological Survey, 2020b, USGS surface-water data for the Nation, in USGS water data for the Nation: U.S. Geological Survey National Water Information System database, accessed January 3, 2020, at https://doi.org/10.5066/ F7P55KJN. [Surface-water data directly accessible at https:/ /waterdata.usgs.gov/nwis/sw.]

U.S. Geological Survey, 2020c, USGS 06893750 Little Blue River at Grandview, Mo., in USGS water data for the Nation: U.S. Geological Survey National Water Information System database, accessed January 4, 2020, at https://doi.org/10.5066/F7P55KJN. [Site information directly accessible at https://waterdata.usgs.gov/nwis/uv? site_no $=06893750$.] 
U.S. Geological Survey, 2020d, USGS 384950094330701

Eagles' Landing, in USGS water data for the Nation: U.S. Geological Survey National Water Information System database, accessed January 4, 2020, at https://doi.org/10.5066/ F7P55KJN. [Site information directly accessible at https:/ /waterdata.usgs.gov/nwis/uv?site_no $=384950094330701$.]

U.S. Geological Survey, 2020e, USGS 385035094304401 Shalimar Park, in USGS water data for the Nation: U.S. Geological Survey National Water Information System database, accessed January 4, 2020, at https://doi.org/10.5066/ F7P55KJN. [Site information directly accessible at https:/ /waterdata.usgs.gov/nwis/uv?site_no $=385035094304401$.]

U.S. Geological Survey, 2021, WaterAlert: U.S. Geological Survey web-based application, accessed January 20, 2021, at https://maps.waterdata.usgs.gov/mapper/wateralert/.

Voss, J.D., and Heimann, D.C., 2021, Geospatial data and hydraulic-model archive for evaluation of flood-inundation maps developed for a reach of the Little Blue River at Grandview, Missouri: U.S. Geological Survey data release, https://doi.org/10.5066/P9JLOM4K.

Yang, L., Jin, S., Danielson, P., Homer, C., Gass, L., Bender, S.M., Case, A., Costello, C., Dewitz, J., Fry, J., Funk, M., Granneman, B., Liknes, G.C., Rigge, M., and Xian, G., 2018, A new generation of the United States National Land Cover Database-Requirements, research priorities, design, and implementation strategies: ISPRS Journal of Photogrammetry and Remote Sensing, v. 146, p. 108-123. [Also available at https://doi.org/10.1016/j.isprsjprs.2 018.09.006.] 

For more information about this publication, contact: Director, USGS Central Midwest Water Science Center 1400 Independence Road

Rolla, M0 65401

573-308-3667

For additional information, visit: https://www.usgs.gov/ centers/cm-water

Publishing support provided by the

Rolla Publishing Service Center 
